\title{
microRNA-26a Directly Targeting MMPI4 and MMPI6 Inhibits the Cancer Cell Proliferation, Migration and Invasion in Cutaneous Squamous Cell Carcinoma [Retraction]
}

\author{
Zheng W, Li ZY, Zhao DL, Li XL, Liu R. Cancer Manage \\ Res. 2020;12:7087-7095.
}

The Editor and Publisher of Cancer Management and Research wish to retract the published article. Concerns were raised over the alleged image duplication if Figure 6B with similar images from unrelated articles, specifically:

- Figure $6 \mathrm{~B}$, all panels, appear to have been duplicated with similar images in Figure 5B from $\mathrm{Mu}$ et al (https://doi.org/10.18632/aging.103918) and Figure 6B from Zhao et al, 2020 (https://doi.org/10. 18632/aging.103275).
The authors did not respond to our queries and the Editor determined the findings of the study were no longer valid and advised for the article to be retracted.

Our decision-making was informed by our policy on publishing ethics and integrity and the COPE guidelines on retraction.

The retracted article will remain online to maintain the scholarly record, but it will be digitally watermarked on each page as "Retracted".

\section{Publish your work in this journal}

Cancer Management and Research is an international, peer-reviewed open access journal focusing on cancer research and the optimal use of preventative and integrated treatment interventions to achieve improved outcomes, enhanced survival and quality of life for the cancer patient.
The manuscript management system is completely online and includes a very quick and fair peer-review system, which is all easy to use. Visit http://www.dovepress.com/testimonials.php to read real quotes from published authors. 